удк 343.977

О. П.Фролов

\title{
СПЕЦИФІКА ДЕЯКИХ СУБ'СКТІВ ОБШУКУ У ФОРМІ СПЕЦІАЛЬНОЇ ОПЕРАЦІЇ
}

Постановка проблеми та ії актуальність. Досудове розслідування та встановлення обставин, що мають значення для кримінального провадження, особливо щодо злочинів у сфері господарської діяльності, як правило, неможливе без дослідження досить значної кількості предметів і документів, пов'язаних з діяльністю підприємств, установ та організацій. За таких умов чи не першочерговою слідчою (розшуковою) дією, що проводиться після внесення відповідних відомостей до Єдиного реєстру досудових розслідувань та початку розслідування, є обшук. На стадії збирання, перевірки та оцінки доказів, виявлення і закріплення слідів злочину обшук є важливою невідкладною слідчою (розшуковою) дією.

Розглядаючи загальні положення проведення обшуку у формі спеціальної операції, ми вже приділяли увагу особам (суб’єктам обшуку), що беруть участь у здійсненні таких заходів [1, с. 196-198]. Разом із тим кожен із суб'єктів обшуку у формі спеціальної операції, виходячи з її розуміння, ознак і особливостей організації, має свою специфіку, що потребує більш детального розгляду.

Аналіз останніх досліджень та публікацій. Темі обшуку в кримінально-процесуальній і криміналістичній літературі приділено значну увагу. Вагомий внесок у розроблення наукових засад проведення обшуку зробили відомі вчені, зокрема О.Я. Баєв, В.П. Бахін, Р.С. Бєлкін, О.М. Васильєв, С.Ф. Денисюк, I.І. Когутич, В.І. Комісаров, А.А. Леві, А.І. Михайлов, М.М. Михеєнко, В.М. Нікіфоров, В.Т. Нор, М.В. Салтевський, В.Ю. Шепітько та ін. Проте у більшості цих робіт не розглядалася специфіка проведення широкомасштабних обшуків у формі спеціальної операції, що має певні тактико-криміналістичні і процесуальні особливості.

Метою статті є розкриття поняття, основних рис та специфіки деяких суб'єктів обшуку у формі спеціальної операції.

Виклад основного матеріалу. Обшук є однією з невідкладних слідчих (розшукових) дій, що регламентуеться ст.ст. 233-236 Кримінального процесуального кодексу України (далі - КПК України). У сучасних умовах він набув нових особливостей та проводиться у значній кількості кримінальних проваджень у новій організаційній формі - формі спеціальної операції.

Ми вже раніше пропонували власне визначення понять «спеціальна операція» та «обшук у формі спеціальної операції».

На нашу думку, спеціальна операція - це не процесуальний різновид, тобто не нова слідча (розшукова) дія, а тільки нова організаційна форма її здійснення (натепер будьяких специфічних норм, що регламентують провадження слідчих (розшукових) дій саме в формі спеціальної операції, законом не передбачено). Спеціальна операція - це складна організаційна форма здійснення слідчої (розшукової) дії, яка характеризується великою кількістю суб’єктів і грунтується на збиранні та дослідженні на значній території багатьох об'єктів, що несуть значиму для кримінального провадження криміналістичну інформацію [2, с. 320-321]. 
Обшук у формі спеціальної операції - це характерна для сучасних умов нова організаційна форма провадження слідчої (розшукової) дії, яка полягає у примусовому дослідженні приміщень (споруд), що мають значну за розмірами площу і (або) розділених на багато кімнат (відсіків), великих ділянок місцевості, а також крупних транспортних засобів, значною кількістю суб’єктів з метою відшукання та вилучення множинних приховуваних слідів злочинної діяльності, предметів і цінностей, набутих злочинним шляхом, які підлягають конфіскації, розшуку осіб і трупів, що здійснюється в умовах подолання протидії розслідуванню або загрози такої протидії [2, с. 323].

Класифікація суб’єктів обшуку у формі спеціальної операції може бути представлена у такому вигляді.

Першу групу становлять особи, що проводять обшук, тобто суб’єкти, що здійснюють від імені держави і в рамках кримінального провадження дослідження обшукуваного об'єкта з метою відшукання і вилучення знарядь злочину, майна, здобутого злочинним шляхом, інших предметів, документів і цінностей, що мають значення для кримінального провадження. До цієї групи належать: слідчі; керівник органу досудового розслідування; прокурори; інші службові особи, які беруть участь у проведенні обшуку (працівники оперативних підрозділів та підрозділів фізичного захисту відповідно до ст. 41 КПК України); спеціалісти [1, с. 197].

Другу групу становлять суб’єкти, у яких проводиться обшук у формі спеціальної операції, - «обшукувані суб'єкти». До цієї групи належать: особи, які підлягають особистому обшуку; повнолітні особи, що мають відношення до обшукуваного об'єкта (особи, що проживають або працюють у такому місці, володіють або користуються цим об’єктом, а також їхні колеги, знайомі, родичі тощо); захисники й адвокати (ці суб'єкти віднесені нами до групи обшукуваних, оскільки захищають або представляють їхні інтереси); працівники приватних охоронних підприємств, особисті тілоохоронці, інші особи, що здійснюють охоронні функції (ці суб’єкти доволі часто можуть здійснювати активний опір розслідуванню, у тому числі фізичний опір, який має бути подоланий суб’єктами, що належать до першої групи).

Третю групу становлять інші особи, запрошені до участі в проведенні обшуку: потерпілий, його представник та законний представник; підозрюваний, обвинувачений (підсудний), засуджений, виправданий, особа, стосовно якої передбачається застосування примусових заходів медичного чи виховного характеру або вирішувалося питання про їх застосування, їхні захисники та законні представники; поняті; інші учасники кримінального провадження (цивільний позивач, його представник та законний представник, особа, стосовно якої розглядається питання про видачу в іноземну державу (екстрадицію), заявник, свідок та його адвокат, заставодавець, перекладач тощо); інші особи [1, с. 198].

Давайте розглянемо специфіку деяких суб'єктів обшуку у формі спеціальної операції.

Слідчий відповідно до п. 17 ч. 1 ст. 3 КПК України визначається як службова особа відповідних державних органів, уповноважена в межах компетенції, передбаченої цим Кодексом, здійснювати досудове розслідування кримінальних правопорушень. Повний перелік повноважень слідчого, якими його наділено для виконання зазначеної функції, визначено у ст. 40 КПК України. Зокрема, відповідно до п.п. 2, 3 ч. 2 цієї статті слідчий 
уповноважений проводити слідчі (розшукові) дії та негласні слідчі (розшукові) дії у випадках, встановлених цим Кодексом та доручати проведення слідчих (розшукових) дій та негласних слідчих (розшукових) дій відповідним оперативним підрозділам.

Вочевидь, що для проведення традиційного обшуку цілком досить присутності одного слідчого, який може особисто здійснити або проконтролювати цей захід, що проводиться на незначній території за участю невеликої кількості суб’єктів.

Дещо по-іншому ситуація складається у разі проведення обшуку у формі спеціальної операції. Обшук у такій організаційній формі тактично схожий з груповим обшуком, оскільки обшукуваний об'єкт має велику площу і для здійснення пошуку його доцільно поділити на окремі дільниці або сектори. Безперечно, один слідчий не зможе особисто керувати пошуковими заходами, що проводяться на кожній такій дільниці. У такому разі доцільно залучити для проведення обшуку у формі спеціальної операції декількох слідчих, які будуть керувати окремими ділянками (секторами) обшуку. У такому разі в спеціальній операції є доцільною участь керівника органу досудового розслідування, який відповідно до своїх повноважень, передбачених ст. 39 КПК України, може як просто контролювати роботу своїх підлеглих, так і особисто очолити спеціальну операцію.

Прокурор. У п. 15 ч. 1 ст. 3 КПК України зазначається, що під цим терміном розуміються службові особи, перелічені в законі, які діють у межах повноважень, визначених цим Кодексом. Функція прокурора на стадії досудового розслідування відповідно до ч. 2 ст. 36 КПК України визначається як нагляд за додержанням законів під час проведення досудового розслідування у формі процесуального керівництва досудовим розслідуванням. Повний перелік повноважень прокурора, якими його наділено для виконання зазначеної функції, визначено у ст. 36 КПК України. Зокрема, згідно з п.п. 4, 5 ч. 2 цієї статті, прокурор уповноважений доручати слідчому, органу досудового розслідування проведення у встановлений прокурором строк слідчих (розшукових) дій, негласних слідчих (розшукових) дій, інших процесуальних дій або давати вказівки щодо їх проведення чи брати участь у них, а в необхідних випадках - особисто проводити слідчі (розшукові) дії та процесуальні дії в порядку, визначеному цим Кодексом, а також доручати проведення слідчих (розшукових) дій та негласних слідчих (розшукових) дій відповідним оперативним підрозділам.

Вочевидь під час проведення обшуку у формі спеціальної операції прокурор відповідно до своїх повноважень може як контролювати роботу слідчих та співробітників оперативних підрозділів, які за його дорученням виконують зазначену слідчу (розшукову) дію, так і особисто очолити спеціальну операцію.

Співробітники оперативних підрозділів. Відповідно до п. 5 ч. 2 ст. 36 , п. 3 ч. 2 ст. 40 КПК України прокурор, слідчий уповноважені доручити проведення слідчих (розшукових) дій та негласних слідчих (розшукових) дій відповідним оперативним підрозділам.

Оперативні підрозділи здійснюють слідчі (розшукові) дії та негласні слідчі (розшукові) дії в кримінальному провадженні за письмовим дорученням слідчого, прокурора (ч. 1 ст. 41 КПК України).

Практика показує, що без участі співробітників оперативних підрозділів натепер не проводиться жодного обшуку. Більше того, здебільшого слідчий, будучи завантаженим, 
взагалі не присутній під час проведення обшуку, а доручає його проведення співробітникам оперативних підрозділів, які відповідно до ч. 2 ст. 41 КПК України під час виконання доручень слідчого, прокурора користуються повноваженнями слідчого.

Під час проведення обшуку у формі спеціальної операції доцільне залучення значної кількості співробітників оперативних підрозділів, а також керівників оперативних підрозділів. У таких заходах можуть брати участь не один, а декілька оперативних підрозділів різної фахової направленості і різних відомств. Основною функцією співробітників оперативних підрозділів є безпосереднє здійснення пошукових заходів, але за недостатньої кількості слідчих вони можуть керувати окремими ділянками таких заходів, а також виконувати інші функції.

Спеціаліст. Спеціалістом у кримінальному провадженні є особа, яка володіє спеціальними знаннями та навичками застосування технічних або інших засобів і може надавати консультації під час досудового розслідування і судового розгляду з питань, що потребують відповідних спеціальних знань і навичок (ч. 1 ст. 71 КПК України).

3 метою одержання допомоги з питань, що потребують спеціальних знань, слідчий, прокурор для участі в обшуку має право запросити спеціалістів (ч. 1 ст. 236 КПК України). Однак, якщо під час проведення традиційного обшуку запрошується один спеціаліст (іноді два чи три), що має, як правило, криміналістичні знання, то для обшуку у формі спеціальної операції необхідна більша кількість спеціалістів, які мають більш широкий спектр спеціальних знань, оснащені спеціальною технікою і залучаються для надання допомоги у виявленні, фіксації та вилученні доказів.

Працівники підрозділів фізичного захисту. Працівники спецпідрозділів силових структур правоохоронних органів, у тому числі і працівники підрозділів фізичного захисту, у своїй більшості перебувають на штатних посадах оперативних уповноважених, тобто є співробітниками оперативних підрозділів, а тому відповідно до ч. 1 ст. 41 КПК України вони можуть здійснювати слідчі (розшукові) дії та негласні слідчі (розшукові) дії в кримінальному провадженні за письмовим дорученням слідчого, прокурора, користуючись при цьому повноваженнями слідчого (ч. 2 ст. 41 КПК України).

Підрозділи фізичного захисту залучаються для участі в слідчих (розшукових) діях та інших заходах у випадках, коли є реальна загроза активного, у тому числі збройного опору і непокори законним вимогам службових осіб, що їх проводять, у тому числі і під час проведення обшуку у формі спеціальної операції.

Особи, що мають відношення до обшукуваного об’єкта. Під час обшуку у формі спеціальної операції до групи таких осіб, з нашої точки зору, належать: особа (особи), що володіє обшукуваним об’єктом (фізичні особи або представники юридичної особи, у яких обшукуваний об’єкт перебуває на балансі); особи, що проживають на території обшукуваного об’єкта (якщо цей об'єкт належить до житлового сектору); керівники і співробітники підприємств, установ та організацій, на території яких проводиться обшук; інші особи, що перебувають на території обшукуваного об’єкта в момент проведення обшуку (клієнти банку, відвідувачі комерційної фірми, водії автотранспорту, що розвантажується або завантажується на території обшукуваного об’єкта); інші суб'єкти.

Інші особи. Серед інших осіб, так або інакше присутніх під час проведення обшуку у формі спеціальної операції, особливу увагу необхідно приділити представникам засобів масової інформації. Дуже часто кримінальні провадження, що потребують 
здійснення такого роду обшуків, мають великий суспільний резонанс і тому не можуть залишитись поза увагою журналістів. Як показує практика, представники засобів масової інформації прибувають на місце проведення обшуку у формі спеціальної операції, як тільки він розпочинається.

На нашу думку, деякі журналісти можуть бути присутніми на обшукуваному об’єкті і навіть особисто спостерігати за окремими елементами спеціальної операції, якщо це з організаційних або тактичних міркувань не буде заважати роботі службових осіб, що проводять обшук. Рішення про допуск або видалення окремих представників засобів масової інформації приймає особа, що здійснює загальне керівництво спеціальною операцією (слідчий, прокурор, керівник органу досудового розслідування). Також можлива спеціальна акредитація журналістів, що мають право бути присутніми під час здійснення таких заходів.

Слідчо-оперативна група та їі структура. Як вважає Р.С. Бєлкін, слідчо-оперативна група - це одна з організаційних форм розслідування злочинів, що забезпечує ефективну взаємодію слідчого з органом дізнання, спеціалістами, експертами та іншими учасниками групи [3, с. 202].

На думку О.В. Синєокого, характерними ознаками слідчо-оперативної групи є організованість, спільність мети і завдань, тимчасовий характер діяльності, участь представників різних служб і відомств, пріоритет процесуального керівництва, поєднання в межах одного процесуального формування засобів і методів роботи, притаманних суб'єктам із різним процесуальним статусом, сталість ії складу [4, с. 44-45].

Розглядаючи вказані визначення стосовно проведення обшуку у формі спеціальної операції, можна зазначити, що слідчо-оперативна група - це сукупність усіх суб'єктів обшуку у формі спеціальної операції, що проводять дослідження обшукуваного об'єкта з метою відшукання та вилучення предметів, документів та цінностей, які мають значення для кримінального провадження.

Слідчо-оперативна група - це організаційна форма взаємодії слідчих та працівників оперативних підрозділів, що полягає у здійсненні досудового розслідування слідчим (декількома слідчими) та за його (їх) письмовим(и) дорученням(и) здійснення слідчих (розшукових) дій працівниками оперативних підрозділів у кримінальному провадженні, за яким проводиться обшук, а також приданих сил, тобто співробітників, що залучені до участі у справі тільки на час проведення спеціальної операції. До складу слідчо-оперативної групи можуть бути включені і співробітники, які не задіяні безпосередньо у обшуку, а додаткові сили або співробітники, що проводять одночасно зі спеціальною операцією інші слідчі (розшукові) дії. Слідчо-оперативну групу очолює керівник спеціальної операції.

Керівник спеціальної операції (керівник слідчо-оперативної групи) - особа, що здійснює загальне керівництво проведенням обшуку у формі спеціальної операції. Під час обшуку у формі спеціальної операції, на наш погляд, керівником слідчо-оперативної групи може бути слідчий, що проводить досудове розслідування, за яким проводиться обшук, начальник слідчого відділу або прокурор, що здійснює процесуальне керівництво досудовим розслідуванням.

У особливо складних ситуаціях для керівництва слідчо-оперативною групою може створюватися спеціальний оперативний штаб, який виконує функції щодо керівництва, координації та забезпечення діяльності, збору та аналізу відповідної інформації тощо. 
Оперативний штаб - колегіальний орган, що керує слідчо-оперативною групою, створеною для проведення обшуку у формі спеціальної операції в особливо складних умовах з метою координації та забезпечення іï діяльності. Оперативний штаб очолює керівник спеціальної операції. В оперативний штаб обов'язково включається слідчий, що проводить досудове розслідування у кримінальному провадженні, якщо він не $€$ керівником спеціальної операції.

Основною структурною ланкою слідчо-оперативної групи є пошукова група.

Пошукова група - група осіб, що здійснює пошукові заходи на окремій ділянці обшукуваного об'єкта. Вона складається з керівника та членів пошукової групи (співробітники оперативного підрозділу, спеціалісти).

Керівник пошукової групи - особа, що безпосередньо керує пошуковими заходами на окремій ділянці обшукуваного об’єкта. Керівником пошукової групи може бути слідчий або за дорученням слідчого, прокурора найбільш підготовлений співробітник оперативного підрозділу.

Висновки. Отже, підсумовуючи викладене, можна дійти висновку, що кожен із перерахованих суб’єктів обшуку у формі спеціальної операції має свою специфіку, яка в сучасних умовах може мати різні варіативні комбінації та набувати більш широкого змісту.

\section{Jimepamypa}

1. Фролов О.П. Суб’єкти обшуку у формі спеціальної операції (загальна характеристика). Тези доповідей всеукраїнської науково-практичної конференції (м. Харків, 21 листопада 2018 р.) «Актуальні питання досудового розслідування та тендениї розвитку криміналістичної методики». 2018. С. 196-198.

2. Фролов О.П. Поняття та основні риси обшуку у формі спеціальної операції. Міжнародний юридичний вісник: актуальні проблеми сучасності (теорія та практика ). 2018. Вип. 1-2 (10-11). С. 318-324.

3. Белкин Р.С. Криминалистическая энциклопедия. Москва : Мегатрон - XXI, 2000. 333 c.

4. Синєокий О.В. Теоретичні та практичні проблеми діяльності міждержавних змішаних слідчооперативних груп. Криміналістичний вісник : наук.-практ. зб. Ін Юре, 2009. № 1(11). 200 с.

\section{Анотація}

Фролов О. П. Специфіка деяких суб’єктів обшуку у формі спеціальної операції. - Стаття.

У статті розглянуто нову організаційну форму проведення обшуку - спеціальну операцію. Сформовано поняття й ознаки обшуку, який проводиться у цій формі, розкрито його суб'єктивні елементи та розглянуто специфіку деяких суб'єктів.

Ключові слова: обшук, спеціальна операція, обшук у формі спеціальної операції, суб’єкти обшуку, слідча (розшукова) дія.

\section{Аннотация}

Фролов А. П. Специфика некоторых субъектов обыска в форме специальной операции. - Статья. В статье рассматривается новая организационная форма проведения обыска - специальная операция. Сформированы понятия и признаки обыска, который проводится в этой форме, раскрыты его субъъективные элементы и рассмотрена специфика некоторых субъъектов.

Ключевые слова: обыск, специальная операция, обыск в форме специальной операции, субъекты обыска, следственное (розыскное) действие.

\section{Summary}

Frolov O.P. Specificity of some subjects of the search in the form of a special operation. - Article.

The article deals with the new organizational form of the search - a special operation. The concept and signs of the search, which is carried out in this form, reveal its subjective elements and consider the specifics of some subjects.

Key words: search, special operation, search in the form of a special operation, subjects of the search, investigative (search) action. 